\title{
SIGNIFICANCE OF GENOTYPIC ALPHA GALACTOSIDASE A MUTATIONS IN FABRY DISEASE TREATMENT
}

\author{
Jelena Randjelović1,2, Mina Cvetković1,2, Tamara Vrećić1,2, Andriana Jovanović1,2, \\ Marina Randjelović1,3, Tatjana Cvetković1,2
}

\begin{abstract}
Fabry disease (FD) is a rare inherited $X$-linked lysosomal storage disorder caused by a deficiency in alfa-galactosidase A (a-GAL). It is resulting in the accumulation of glycosphingolipids that leads to multiple organ dysfunction and ultimately signs and symptoms of the disease. The aim of this study was to examine the significance of genotypic a-GAL mutations in the treatment of FD. The disease can be divided into a severe, classical phenotype, and a milder nonclassical phenotype. Numerous a-GAL mutations are described in gene mutation databases. Missense, nonsense, consensus splice site, cryptic splicing, and frameshift mutations are reported. Enzyme replacement therapy (ERT) can lead to a significant clinical improvement. Depending on the a-GAL mutation, there are various recommendations for initiation of ERT in adult male and female patients with classic Fabry mutations, later-onset Fabry mutations or aGAL variants of unknown significance. ERT with recombinant human agalsidase alfa and agalsidase beta is currently available therapy. Although there are no uniform guidelines, development of signs or symptoms related to FD should be an indication to start ERT. Treatment with ERT should be combined with adjuvant treatments for specific disease manifestations. Migalastat is a new oral pharmacological molecule developed as an alternative treatment to intravenous ERT for patients with FD and amenable mutations. Migalastat and ERT have similar effects on renal function in patients with FD. Long-term treatment of adult Fabry patients should involve timely ERT, regular assessment of disease progression in all patients, use of appropriate adjunctive therapies and multidisciplinary team approach.
\end{abstract}

Acta Medica Medianae 2020;59(1):76-82.

Key words: Fabry disease, alfa-galactosidase A mutations, treatment

${ }^{1}$ University of Niš, Faculty of Medicine, Niš, Serbia
${ }^{2}$ Clinical Center of Niš, Niš, Serbia

${ }^{3}$ Public Health Institute Niš, Serbia

Contact: Jelena Ranđelović

$11 / 23$ Velikotrnavska, 18000 Niš, Serbia

E-mail: jelenastole@yahoo.com

\section{Introduction}

Alfa-galactosidase A (a-GAL) is an enzyme that cleaves the terminal a-galactosyl unit of the agal epitopes and converts this epitope into a disaccharide called $\mathrm{N}$-acetyllactosamine. This enzyme predominantly hydrolyzes ceramide trihexoside, and it can catalyze the hydrolysis of melibiose into galactose and glucose. The enzyme is encoded by the aGAL gene. Defects in human a-GAL result in Fabry disease (FD), because of failure to catabolize a-D- galactosyl glycolipid moieties $(1,2)$. FD is a rare inherited $X$-linked lysosomal storage disorder caused by a deficiency in alfa-galactosidase $A$ (a-GAL), which removes terminal galactose from various galacto-glycolipids (3). It is resulting in accumulation of glycosphingolipids with terminal a-D-galactosyl residue, particularly globotriaosylceramide and globotriaosylsphingosine, in plasma, vascular endothelial cells, podocytes, cardiomyocytes, and arterial smooth muscle cells (4-6).

Although the exact pathophysiology of FD is still only partly understood, this accumulation of glycosphingolipids leads to multiple organ involvement and ultimately signs and symptoms of the disease (7). This multisystem disorder is manifested by developing progressive proteinuric kidney disease, a fibrotic cardiac disease resulting in rhythm and conduction disturbances, progressive hypertrophic cardiomyopathy, small-fiber neuropathy, and mostly ischemic cerebrovascular stroke (4). Although FD is $\mathrm{X}$-linked disorder, women often have less severe signs and symptoms of FD, compared with men (8). Cardiac involvement contributes to considerable morbidity and early death due to heart failure or ventricular arrhythmias. The incidence of FD has been estimated to be approximately 1 in 40,000 to 1 
in 117,000 male $(9,10)$. Prevalence of FD may be much higher than previously believed. High incidence of later-onset FD was revealed by newborn screening ( 1 in 1,250 to 1 in 3,100 male newborns). Data in the literature shows that $1.2 \%$ of young patients with the unexplained acute cerebrovascular disease have FD (11-13).

The disease can be divided into a severe, classical phenotype, and a milder nonclassical phenotype. Patients with classical FD had a history of more events than patients with nonclassical disease and they are more likely to develop complications. Patients with classical FD most often have symptoms such as neuropathic pain, cornea verticillata, and angiokeratoma. Clinical manifestations include hypertrophic cardiomyopathy, arrhythmias, progressive renal failure, and stroke. Furthermore, patients with classical FD have lower glomerular filtration rate (GFR), higher left ventricular mass and higher plasma globotriaosylsphingosine concentrations than patients with nonclassical FD. Nonclassical FD is characterized by a more variable disease course, patients are generally moderately and mildly affected and disease manifestations may be limited to a single organ $(4,14,15)$. There are described various manifestations of FD, as a cardiac variant with manifestations limited to the heart (with left ventricular hypertrophy of unknown etiology) and a renal variant among hemodialysis patients with unknown etiology. Lung manifestations, as dyspnea, wheezing and a dry cough are frequent symptoms in many Fabry patients (16). Thus, the great importance for the treatment of FD is accurate and early diagnosis $(13,17,18)$.

There is a wide phenotypic variability among patients with FD. Patients with missense a-GAL mutations and variable residual enzyme activity have milder disease manifestations. For example, the N215S mutation may have residual enzyme activity in plasma. In heterozygous females, random X-inactivation may result in the normal level of a-GAL activity in the plasma or white blood cells in up to $60 \%$ of women (19). FD in early adulthood is characterized by more extensive angiokeratomas, high albuminuria (> $1 \mathrm{~g} / 24$ hours), edema or lymphedema, fever, hypohidrosis or anhidrosis, lymphadenopathy, heat sensitivity, diarrhea, abdominal pain, and cardiac problems. FD in later adulthood is manifested by heart disease (usually fibrotic, left and right ventricular hypertrophy, heart valve abnormalities and dysrhythmias, angina, diastolic heart failure), chronic kidney disease including end-stage renal disease, stroke or transient ischemic attacks and deafness (19-22).

The aim of this study was to examine the significance of genotypic a-GAL mutations in the treatment of FD. The data used in the research are obtained from the books and relevant literature by means of PubMed browser.

\section{Genetics}

The complete genomic sequences of the human a-GAL gene have been determined and to date, several disease-causing a-GAL mutations have been identified, including missense mutations, small dele- tions, insertions, splice mutations, and large gene rearrangements (23).

More than 500 pathologic variants of a-GAL have already been described; most of them are family-specific. Numerous a-GAL mutations are described in gene mutation databases $(24,25)$. FD is caused by missense, nonsense, consensus splice site, cryptic splicing, and frameshift mutations (small and large deletions and insertions). Mentioned mutations are associated with the classic or later-onset FD phenotype, a-GAL variants of unclear significance, and benign variants. Patients with missense and nonsense mutations have nearly absent GLA activities and increased lyso- globotriaosylceramide levels $(20,26)$.

Patients with mutations within intronic or regulatory a-GAL regions have nonclassical FD phenotypes accompanied by late-onset organ manifestations such as cardiomyopathy, kidney failure, stroke, or neuropathic pain. The clinical impact of the a-GAL p.A143T variation in adult Fabry patients was determined in the recent study and patients with this mutation have clinical symptoms and manifestations compared with other classical missense mutations. Most male p.A143T patients had only slightly decreased residual a-GAL activities and normal lysoGb3 levels, while a-GAL activity in heterozygous females was normal. Female and male p.A143T patients had a less renal and cardiac involvement in comparison to FD patients with other missense mutations and these patients showed less severe FDtypical symptoms. Both gender p.A143T patients suffering from stroke or transient ischemic attack showed no further FD-typical organ manifestations. The risk for albuminuria and increased disease severity scores was significantly lower in p.A143T patients in comparison to groups with classical FD missense mutations. There was no accumulation of neurologic events in family members of p.A143T patients with stroke or transient ischemic attack. Female p.A143T patients with stroke or TRANSIENT ISCHEMIC ATTACK did not show skewed X chromosome inactivation. This study suggested the p.A143T variation to be more likely a neutral variant or a genetic modifier than a disease causing mutation. p.A143T could be a genetic variant of unknown significance. Thus, recommendation is that p.A143T patients with stroke or TRANSIENT ISCHEMIC ATTACK of unknown etiology should be further evaluated, since the diagnosis of FD is not probable and enzyme replacement therapy (ERT) or chaperone treatment should not be an unreflected option (27).

The multiplicity of mutations may contribute to variations in the residual enzyme activity and the different clinical presentations. Most of a-GAL gene variants is unique for each family. In study on FD screening in a predominantly hypertensive population with left ventricular hypertrophy (LVH) was found a mutation of unknown significance in a-GAL gene not previously described in the literature - GLA c.785G >T; p.W262L, whose significance could not be defined. This clinical investigation was able to establish the association between the mutation and the clinical presentation. It is also documented that the clinical management required defining the role of the mutation on the development of the clinical 
presentation. This study allowed the definition of a novel causal mutation for Fabry disease - GLA c.785G > T; p.W262L (28).

Two new mutations were identified in Turkey. The female patient with M11V mutation had rheumatologic symptoms and microalbuminuria. The male patient with R190X mutation had a classical phenotype. R190X mutation causes premature termination, and probably leads to degradation of the protein (29).

Benign and probably benign variants have a high frequency. Medical specialists should be aware that, due to this high frequency, such mutations may be seen in screening studies. This benign polymorphism may not be related to actual Fabry-related manifestations, as there is no published evidence of lysosomal substrate accumulation in the tissues expressing them (30). Most often, nonsense, consensus splice site, and most frameshift mutations are associated with the classic phenotype. They result in low or no a-GAL enzyme activity. On the other side, missense mutations and rare cryptic splicing mutations are associated with the lateronset phenotypes and they result in enzymes with residual a-GAL activity. Current clinical studies have not stratified Fabry patients by genotype $(26,31)$.

Women with heterozygous a-GAL mutations suffer from significant multisystemic disease and reduced quality of life and must be monitored and treated accordingly. The asymptomatic female carrier of FD is the exception, not the rule (32). In female heterozygous Fabry patients who express the normally functioning a-GAL allele, symptoms are mild and rarely occur, while female patients who express the mutant a-GAL allele have a disease course which may be similar to the male disease phenotype (either classic or later-onset). It depends on the underlying a-GAL mutation in their family. At least $43 \%$ of obligate carrier women have severe clinical manifestations (33). While the onset of first Fabry-associated symptoms in affected hemizygous males with low or absent enzymatic a-GAL activity starts in early childhood, females with FD present with a heterogeneous clinical picture and variable disease progression, independent of the presence of a nonsense or a missense mutation. Recent study showed that although females with missense mutations seem to have a lower risk to suffer from severe FD manifestations, affected females showed a similar disease burden compared to females with nonsense mutations. The variation and the missing genotype-phenotype correlation might be due to the controversially discussed $\mathrm{X}$-chromosomal inactivation.

Individuals with the c.196G > C nucleotide change which leads to the E66Q enzyme having low a-GAL activity and they have been suspected to have the later-onset Fabry disease phenotype leading to renal and cardiac disease. Biochemical, pathological and structural studies strongly suggest that the c.196G > C is not a pathogenic mutation but is a functional polymorphism (34).

Analysis of genotype-phenotype correlations in FD is complicated by a number of factors, such as the high proportion of private mutations and the large phenotypic heterogeneity (35). Some geno- type-phenotype correlations, as the missense mutation p.N215S is established in patients with cardiac manifestations (hypertrophic cardiomyopathy) (36). Determining genotype-phenotype relationships is important for the assessment of whether affected patients may benefit from ERT. The atypical or lateonset type phenotypes present a therapeutic dilemma.

The genetic background of the patient, concomitant diseases, environmental modifiers and the presence of additional deleterious a-GAL variants or variants of unknown significance may alter the impact of a given gene mutation (30).

\section{Management recommendations}

Enzyme replacement therapy (ERT) can lead to significant clinical improvement. ERT with recombinant human agalsidase alfa and agalsidase beta is currently available therapy aimed at the etiology of FD. There is no scientific evidence when the optimal moment of ERT initiation is. Although there are no uniform guidelines, development of signs or symptoms related to FD should be an indication to start ERT. If ERT has not already been started earlier for nonrenal manifestations such as pain, the development of chronic kidney disease (CKD), pathological albuminuria, decreased GFR or progressive decrease in GFR may be an indication to start (37). Research recommendations for initiation of therapy include:

1) determination of the beginning treatment in asymptomatic patients, females, patients with nonclassic disease;

2) obtaining expanded information on the natural history of FD in classic female patients and nonclassic FD patients, and the effects of ERT in these groups and

3) undertaking $X$-linked inactivation studies and early initiation of therapy in females (19).

Depending on the mutation there are various recommendations for initiation of ERT in adult male and female patients with classic Fabry mutations, later-onset Fabry mutations or a-GAL variants of unclear significance. Depending on the approach to treatment, patients with classic Fabry mutation can be divided into three groups: symptomatic or asymptomatic male patients, symptomatic female patients, and asymptomatic female patients. In the first group, ERT should be considered and is appropriate in all patients at any age of presentation. Treatment decisions may be influenced by the advanced elderly age of the patient and severe comorbidity. In the second group, initiation of ERT is warranted when signs and symptoms suggesting major organ involvement occur. In the third group, ERT should be considered if there is a laboratory, histological, or imaging evidence of kidney, heart, or the cerebral injury. ERT should also be considered if a skewed $X$ chromosome inactivation pattern with predominant expression of the mutant a-GAL allele with or without very low a-GAL activity has been demonstrated in the presence of signs and symptoms of the disease. Male and female patients with lateronset Fabry mutation or missense a-GAL variants of unclear significance should start ERT if there is a 
laboratory, histological, or imaging evidence of injury to the kidney, heart, or the central nervous system, even in the absence of typical Fabry symptoms. The abnormalities should be attributable to $\mathrm{FD}$; this may require histological assessment or biochemical evidence of globotriaosylceramide accumulation. The advice of an expert in genetics and management of FD should be sought for interpretation of the pathogenicity of any a-GAL variants of unclear significance. Individuals with well-characterized benign a-GAL polymorphisms should not be treated with ERT. In the absence of demonstrable FD-related tissue pathology or clinical symptoms, ERT may not be appropriate, particularly in heterozygous female patients. These patients should be monitored regularly by a multidisciplinary care team $(19,37-39)$. Current FD guidelines and recommendations suggest ERT initiation in females with FD after the onset of first FD-typical renal, cardiac, and cerebral complications, or in rapidly progressive disease $(39,40)$. Fifty-seven percent of female FD patients were under ERT, nearly all presented with different organ manifestations that justify ERT initiation according to current European guidelines. One third of females were untreated although indications (organ manifestations). Some of them refused ERT, or can't receive ERT due to pregnancy or future family planning, or they were refusing ERT because of possible benefit from future chaperone treatment (41).

Periodic monitoring of anti-agalsidase antibodies in patients receiving ERT is also recommended, considering these natural defense mechanisms may block the effectiveness of ERT treatment and lead to dose adjustment. Early treatment of FD may improve clinical outcome, initiation of ERT at a younger age in patients with classical FD results in a better biochemical response (42). ERT should not be restricted to hemizygous men but should be considered for both heterozygous females and children (20).

ERT should be combined with adjunctive therapies for adult patients with FD. Renal, cardiac, neurological, gastrointestinal, cerebrovascular and other complications of FD that cause chronic tissue injury should be treated with symptomatic specific therapy (43-45).
Migalastat is an oral pharmacological chaperone developed as an alternative treatment to intravenous ERT for patients with FD and amenable mutations. This new oral small-molecule stabilizes specific mutant (amenable) forms of a-Gal to facilitate normal lysosomal trafficking. In this way, this drug may increase endogenous enzymatic activity in patients with specific missense a-Gal mutations. Migalastat and ERT have similar effects on renal function. There is no significant change in left ventricular mass index in patients treated with Migalastat compared to patients treated by ERT. In randomized, active-controlled study renal, cardiac or cerebrovascular events occurred in $29 \%$ and $44 \%$ of patients in the migalastat and ERT groups, respectively. Plasma globotriaosylsphingosine was low and stable in migalastat treated patient with FD. Migalastat was generally safe and well tolerated (46-48).

\section{Conclusion}

FD affects very emotionally and physically on patients and their families. Long-term treatment of adult patients with FD should include ERT, regular assessment of disease progression, and the use of appropriate adjunctive therapies $(38,40)$.

Numerous a-Gal mutations complicate therapeutic management of this rare chronic disease. FD requires multidisciplinary care in the treatment of organ-specific complications. Active participation of medical specialists experienced in treating this disorder is necessary, as well as communication between the neurologist, nephrologist, cardiologist, medical geneticist, genetic counselor, psychologist, and nurse. Significance of genetic polymorphisms in FD pathology remains unknown (49) and the response to therapy may depend on a-GAL gene mutations.

\section{Acknowledgment}

This study was supported by grant of Ministry of Science and Technological Development - project number 41018. 


\section{References}

1. Scriver $C R$, Beaudet $A L$, Sly WS, Valle $D$, Childs B, Kinzler KW, Vogelstein B, eds. The metabolic and molecular bases of inherited disease. $8^{\text {th }}$ ed. New York:McGraw-Hill;2001.

2. Galili U. The natural anti-Gal antibody as foe turned friend in medicine. Philadelphia:Saunders (Elsevier); 2018.287-300 p. [CrossRef]

3. Swaiman KF, Ashwal S, Ferriero D, Schor N, eds. Swaiman's pediatric neurology: principles and practice. $5^{\text {th }}$ ed. Philadelphia: Saunders (Elsevier); 2012. 107 p. [CrossRef]

4. Desnick R, Ioannou $Y$, Eng C. A-galactosidase a deficiency: Fabry disease. In: Valle $D$, Beaudet $A L$, Vogelstein B, Kinzler KW, Antonarakis SE, Ballabio A, et al., editors. The Online Metabolic and Molecular Bases of Inherited Disease. New York:McGraw-Hill Medical;2014. [CrossRef]

5. Germain DP. Fabry disease. Orphanet J Rare Dis 2010;5:30. [CrossRef] [PubMed]

6. Brady RO, Gal AE, Bradley RM, Martensson E, Warshaw AL, Laster L. Enzymatic defect in Fabry's disease. N Engl J Med 1967;276(21):1163-7. [CrossRef] [PubMed]

7. Schuller $Y$, Arends M, Körver S, Langeveld M, Hollak CEM. Adaptive pathway development for Fabry disease: a clinical approach. Drug Discov Today 2018; 23(6):1251-7. [CrossRef] [PubMed]

8. MacDermot KD, Holmes A, Miners AH. Anderson-Fabry disease: clinical manifestations and impact of disease in a cohort of 60 obligate carrier females. J Med Genet 2001;38(11):769-75. [CrossRef] [PubMed]

9. Ioannou $Y A$, Zeidner $K M$, Gordon RE, Desnick RJ. Fabry disease: preclinical studies demonstrate the effectiveness of alpha-galactosidase A replacement in enzyme-deficient mice. Am J Hum Genet 2001;68 (1):14-25. [CrossRef] [PubMed]

10. Meikle PJ, Hopwood JJ, Clague AE, Carey WF. Prevalence of lysosomal storage disorders. JAMA 1999;281(3):249-54. [CrossRef] [PubMed]

11. Rolfs A, Böttcher $T$, Zschiesche $M$, Morris $P$, Winchester $B$, Bauer $P$, et al. Prevalence of Fabry disease in patients with cryptogenic stroke: a prospective study. Lancet 2005;366(9499):1794-6. [CrossRef] [PubMed]

12. Spada M, Pagliardini S, Yasuda M, Tukel T, Thiagarajan G, Sakuraba $H$, et al. High incidence of later-onset Fabry disease revealed by newborn screening. Am J Hum Genet 2006;79(1):3140. [CrossRef] [PubMed]

13. Yoshimitsu $M$, Higuchi $K$, Miyata $M$, Devine $S$, Mattman A, Sirrs $S$, et al. Identification of novel mutations in the a-galactosidase $A$ gene in patients with Fabry disease: pitfalls of mutation analyses in patients with low a-galactosidase A activity. J Cardiol 2011;57(3):345-53. [CrossRef] [PubMed]

14. Smid $B E$, van der Tol L, Biegstraaten M, Linthorst GE, Hollak CEM, Poorthuis BJHM. Plasma globotriaosylsphingosine in relation to phenotypes of Fabry disease. J Med Genet 2015;52(4):262-8.

[CrossRef] [PubMed]

15. Arends M, Wanner C, Hughes D, Mehta A, Oder D, Watkinson OT, et al. Characterization of classical and nonclassical Fabry disease: A multicenter study. J Am Soc Nephrol 2017;28(5):1631-41.

[CrossRef] [PubMed]
16. Magage S, Lubanda JC, Susa Z, Bultas J, Karetová D, Dobrovolný $R$, et al. Natural history of the respiratory involvement in Anderson-Fabry disease. J Inherit Metab Dis 2007;30(5):790-9. [CrossRef] [PubMed]

17. Sachdev B, Takenaka T, Teraguchi $H$, Tei C, Lee $P$, McKenna WJ, et al. Prevalence of Anderson-Fabry disease in male patients with late onset hypertrophic cardiomyopathy. Circulation 2002;105(12):1407-11. [CrossRef] [PubMed]

18. Nakao S, Kodama C, Takenaka T, Tanaka A, Yasumoto $Y$, Yoshida A, et al. Fabry disease: detection of undiagnosed hemodialysis patients and identification of a "renal variant" phenotype. Kidney Int 2003;64(3):801-7. [CrossRef] [PubMed]

19. Schiffmann $R$, Hughes $D A$, Linthorst $G E$, Ortiz $A$, Svarstad E, Warnock DG, et al. Screening, diagnosis, and management of patients with Fabry disease: conclusions from a "Kidney Disease: Improving Global Outcomes" (KDIGO) Controversies Conference. Kidney Int 2017;91(2):284-93. [CrossRef] [PubMed]

20. Mehta A, Ricci R, Widmer U, Dehout F, Garcia de Lorenzo A, Kampmann C, et al. Fabry disease defined: baseline clinical manifestations of 366 patients in the Fabry Outcome Survey. Eur J Clin Invest 2004; 34(3):236-42. [CrossRef] [PubMed]

21. Ramaswami U, Whybra C, Parini R, Pintos-Morell G, Mehta A, Sunder-Plassmann G, et al. Clinical manifestations of Fabry disease in children: data from the Fabry Outcome Survey. Acta Paediatr 2006; 95(1): 86-92. [CrossRef] [PubMed]

22. MacDermot KD, Holmes A, Miners AH. AndersonFabry disease: clinical manifestations and impact of disease in a cohort of 98 hemizygous males. J Med Genet 2001;38(11):750-60. [CrossRef] [PubMed]

23. Tuttolomondo A, Duro G, Miceli S, Di Raimondo D, Pecoraro R, Serio A, et al. Novel alpha-galactosidase A mutation in a female with recurrent strokes. Clin Biochem 2012;45(16-17):1525-30. [CrossRef] [PubMed]

24. International Fabry Disease Genotype-Phenotype Database (dbFGP). International Fabry Disease Genotype-Phenotype Database (dbFGP) 2016 "cited 2019 Apr 4"; Available from: http://dbfap.org/dbFgp/fabry/

25. The Fabry disease mutation database. "cited 2019 Apr 4";Available from: http://fabry-database.org/ mutants/

26. Niemann M, Rolfs A, Störk S, Bijnens B, Breunig F, Beer $M$, et al. Gene mutations versus clinically relevant phenotypes: lyso-Gb3 defines Fabry disease. Circ Cardiovasc Genet 2014;7(1):8-16. [CrossRef] [PubMed]

27. Lenders M, Weidemann F, Kurschat C, Canaan-Kühl S, Duning T, Stypmann J, et al. Alpha-Galactosidase A p.A143T, a non-Fabry disease-causing variant. Orphanet J Rare Dis 2016;11:54. [CrossRef] [PubMed]

28. Baptista A, Magalhães $P$, Leão $S$, Carvalho $S$, Mateus $P$, Moreira I. Screening for Fabry disease in left ventricular hypertrophy: Documentation of a novel mutation. Arq Bras Cardiol 2015;105(2):139-44. [CrossRef] [PubMed]

29. Celtikci B, Topçu M, Ozkara A. Two novel alphagalactosidase A mutations causing Fabry disease: A missense mutation $\mathrm{M} 11 \mathrm{~V}$ in a heterozygote woman and a nonsense mutation R190X in a hemizygote man. Clin Biochem 2011;44(10-11):809-12. [CrossRef] [PubMed] 
30. Desnick RJ, Doheny DO, Chen B, Yu C, Nazarenko I, Lee $B$, et al. Fabry disease: The a-galactosidase $A$ (GLA) c.427G $>$ A (A143T) mutation, effect of the $5^{\prime}-$ 10C >T polymorphism. Mol Genet Metab 2015; 114 (2):S37. [CrossRef]

31. Ferreira S, Ortiz A, Germain DP, Viana-Baptista M, Caldeira-Gomes A, Camprecios M, et al. The alphagalactosidase A p.Arg118Cys variant does not cause a Fabry disease phenotype: data from individual patients and family studies. Mol Genet Metab 2015; 114(2):248-58. [CrossRef] [PubMed]

32. Wang RY, Lelis A, Mirocha J, Wilcox WR. Heterozygous Fabry women are not just carriers, but have a significant burden of disease and impaired quality of life. Genet Med 2007;9(1):34-45.

[CrossRef] [PubMed]

33. Wilcox WR, Oliveira JP, Hopkin RJ, Ortiz A, Banikazemi $M$, Feldt-Rasmussen $U$, et al. Females with Fabry disease frequently have major organ involvement: Lessons from the Fabry Registry. Mol Genet Metab 2008;93(2):112-28. [CrossRef] [PubMed]

34. Togawa T, Tsukimura T, Kodama T, Tanaka T, Kawashima I, Saito S, et al. Fabry disease: Biochemical, pathological and structural studies of the agalactosidase A with E66Q amino acid substitution. Mol Genet Metab 2012;105(4):615-20.

[CrossRef] [PubMed]

35. Ries M, Gal A. Genotype-phenotype correlation in Fabry disease. In: Mehta A, Beck M, SunderPlassmann G, editors. Fabry Disease: Perspectives from 5 Years of FOS. Oxford: PharmaGenesis; 2006. [CrossRef] [PubMed]

36. Patel V, O'Mahony C, Hughes D, Rahman MS, Coats C, Murphy $E$, et al. Clinical and genetic predictors of major cardiac events in patients with Anderson-Fabry Disease. Heart 2015;101(12):9616. [CrossRef] [PubMed]

37. Beck M, Hughes D, Kampmann C, Larroque S, Mehta A, Pintos-Morell G, et al. Long-term effectiveness of agalsidase alfa enzyme replacement in Fabry disease: A Fabry Outcome Survey analysis. Mol Genet Metab Rep 2015;3:21-7. [CrossRef] [PubMed]

38. Ortiz A, Germain DP, Desnick RJ, Politei J, Mauer M, Burlina $A$, et al. Fabry disease revisited: Management and treatment recommendations for adult patients. Mol Genet Metab 2018;123(4):416-27.

[CrossRef] [PubMed]

39. Biegstraaten $M$, Arngrímsson R, Barbey $F$, Boks $L$, Cecchi F, Deegan PB, et al. Recommendations for initiation and cessation of enzyme replacement therapy in patients with Fabry disease: the European Fabry Working Group consensus document. Orphanet J Rare Dis 2015;10:36. [CrossRef] [PubMed]

40. Eng CM, Germain DP, Banikazemi M, Warnock DG, Wanner C, Hopkin RJ, et al. Fabry disease: Guidelines for the evaluation and management of multi-organ system involvement. Genet Med 2006;8(9):539-48. [CrossRef] [PubMed]

41. Lenders $M$, Hennermann JB, Kurschat $C$, Rolfs $A$, Canaan-Kühl S, Sommer C, et al. Multicenter Female Fabry Study (MFFS) - Clinical survey on current treatment of females with Fabry disease. Orphanet J Rare Dis 2016;11:88.

[CrossRef] [PubMed]

42. Arends $M$, Wijburg FA, Wanner $C$, Vaz FM, van Kuilenburg ABP, Hughes DA, et al. Favourable effect of early versus late start of enzyme replacement therapy on plasma globotriaosylsphingosine levels in men with classical Fabry disease. Mol Genet Metab 2017; 121(2):157-61. [CrossRef] [PubMed]

43. Politei JM, Bouhassira D, Germain DP, Goizet C, Guerrero-Sola A, Hilz MJ, et al. Pain in Fabry disease: Practical recommendations for diagnosis and treatment. CNS Neurosci Ther 2016; 22(7):568-76. [CrossRef] [PubMed]

44. Burlina AP, Sims KB, Politei JM, Bennett GJ, Baron R, Sommer $C$, et al. Early diagnosis of peripheral nervous system involvement in Fabry disease and treatment of neuropathic pain: the report of an expert panel. BMC Neurol 2011;11:61. [CrossRef] [PubMed]

45. Attal N, Cruccu G, Baron R, Haanpää $M$, Hansson $P$, Jensen TS, et al. EFNS guidelines on the pharmacological treatment of neuropathic pain: 2010 revision. Eur J Neurol 2010;17(9):1113-e88. [CrossRef] [PubMed]

46. Hughes DA, Nicholls K, Shankar SP, SunderPlassmann G, Koeller D, Nedd $K$, et al. Oral pharmacological chaperone migalastat compared with enzyme replacement therapy in Fabry disease: 18month results from the randomised phase III ATTRACT study. J Med Genet 2017;54(4):288-96. [CrossRef] [PubMed]

47. Germain DP, Hughes DA, Nicholls $K$, Bichet DG, Giugliani R, Wilcox WR, et al. Treatment of Fabry's disease with the pharmacologic chaperone migalastat. N Engl J Med 2016;375(6):545-55.

[CrossRef] [PubMed]

48. Benjamin ER, Della Valle MC, Wu X, Katz E, Pruthi F, Bond $S$, et al. The validation of pharmacogenetics for the identification of Fabry patients to be treated with migalastat. Genet Med 2017;19(4):430-8.

[CrossRef] [PubMed]

49. Tuttolomondo A, Duro G, Pecoraro R, Simonetta I, Miceli S, Colomba $\mathrm{P}$, et al. A family with various symptomatology suggestive of Anderson-Fabry disease and a genetic polymorphism of alpha galactosidase A gene. Clin Biochem 2015;48(1-2):55-62. [CrossRef] [PubMed] 


\title{
ZNAČAJ GENOTIPSKIH MUTACIJA ALFA GALAKTOZIDAZE A U TERAPIJI FABRIJEVE BOLESTI
}

\author{
Jelena Ranđelović ${ }^{1,2}$, Mina Cvetković ${ }^{1,2}$, Tamara Vrećić1,2, Andriana Jovanović1,2, \\ Marina Ranđelović1,3, Tatjana Cvetković1,2
}

\author{
${ }^{1}$ Univerzitet u Nišu, Medicinski fakultet, Niš, Srbija \\ ${ }^{2}$ Klinički centar Niš, Niš, Srbija \\ ${ }^{3}$ Institut za javno zdravlje Niš, Niš, Srbija \\ Kontakt: Jelena Ranđelović \\ Velikotrnavska 11/23,18000 Niš, Srbija \\ E-mail: jelenastole@yahoo.com
}

Fabrijeva bolest (FB) je retko nasledno „X vezano“ lizozomalno oboljenje izazvano deficijencijom alfa galaktozidaze $A$ (a-GAL). To dovodi do nagomilavanja glikosfingolipida, što dalje vodi do disfunkcije mnogih organa i na kraju do znakova i simptoma bolesti. Cilj ovog rada bio je da se ispita značaj genotipskih mutacija a-GAL u terapiji FB. Bolest se može manifestovati u vidu teškog, klasičnog fenotipa i blagog, neklasičnog fenotipa. Opisane su brojne a-GAL mutacije u bazi podataka o genskim mutacijama, kao što su mutacije pogrešnog smisla (missense), besmislene mutacije (nonsense), mutacije obrade (splice site), kriptičke mutacije (cryptic splicing) i mutacije pomeranja okvira čitanja (frameshift). Terapija zamene enzima (TZE) može doprineti značajnom kliničkom poboljšanju. U zavisnosti od vrste mutacije a-GAL, postoje različite preporuke o započinjanju TZE kod odraslih muškaraca i žena sa klasičnim mutacijama, mutacijama koje dovode do kasnog početka Fabrijeve bolesti i varijantama a-GAL nepoznatog značaja. Trenutno dostupna TZE je primena rekombinantne agalzidaze alfa i agalzidaze beta. Iako nema jedinstvenih vodiča, razvoj znakova i simptoma bolesti trebalo bi da bude indikacija za početak lečenja TZE. Ovu terapiju treba kombinovati sa adjuvantnom terapijom za specifične manifestacije bolesti. Migalastat je novi farmakološki oralni molekul, razvijen kao alternativa intravenskoj TZE za bolesnike sa FB. Migalastat i TZE imaju slične efekte na bubrežnu funkciju kod bolesnika sa ovom bolešću. Dugoročni tretman odraslih bolesnika sa FB treba da podrazumeva pravovremenu TZE, redovno praćenje progresije bolesti svih obolelih, primenu odgovarajuće adjuvantne terapije i multidisciplinarni pristup bolesti.

Acta Medica Medianae 2020;59(1):76-82.

Ključne reči: Fabrijeva bolest, mutacije alfa galaktozidaze $A$, terapija 